\title{
Critical Skill Sets of Entry-Level IT Professionals: An Empirical Examination of Perceptions from Field Personnel
}

\author{
Mark E. McMurtrey, James P. Downey, Steven M. Zeltmann, \\ and William $H$. Friedman \\ University of Central Arkansas, Conway, AR, USA
}

\author{
markmc@uca.edu; jdowney@uca.edu; stevenz@uca.edu; \\ friedman@uca.edu
}

\section{Executive Summary}

Understanding the skill sets required of IT personnel is a critical endeavor for both business organizations and academic or training institutions. Companies spend crucial resources training personnel, particularly new IT employees, and educational institutions must know what skills are essential in order to plan an effective curriculum. Rapid advances in technology, as well as changing IT practices, alter the importance of particular skills for IT professionals over time and therefore necessitate that frequent updates be performed. Additionally, previous studies have found mixed results as to which skills were deemed most important for IT professionals. In order to examine which skills are most critical, a taxonomy was developed from the literat ure that divided 42 potentially important skills into four areas: IS Core Knowledge, T echnical Proficiencies, Business Expertise, and Personal Attributes. This study surveyed 153 IT field personnel from six organizations and empirically examined which skills they thought most important for entry-level IT professionals. Results found that the most important skills for new IT professionals were soft skills, specifically the personal attributes of problem-solving, critical thinking, and team skills. However, the study also found that technical skills were essential, especially database knowledge and proficiency, knowledge of programming languages, object-oriented knowledge, and web development skills. Some skills were not considered very important, particularly specialized software for applications such as decision support systems, expert systems, GIS, and ERP systems. Some skills in the area of business expertise were also rated highly, especially ethics/privacy and security issues. In comparing the four skill areas, the study found that each area was significantly different than the otherthree in terms of importance, in this order: personal attributes, business expertise, IS core knowledge items, and proficiencies. The study also found some significant differences in the importance of some skills depending on the respondent's age,

Material published as part of this publication, either on-line or in print, is copyrighted by the Informing Science Institute. Permission to make digital or paper copy of part or all of these works for personal or classroomuse is granted without fee provided that the copies are not made or distributed for profit or commercial advantage AND that copies 1) bear this notice in full and 2) give the full citation on the first page. It is permissible to abstract these works so long as credit is given. To copy in all other cases or to republish or to post on a serveror to redistribute to lists requires specific permission and payment ofa fee. Contact Publisher@,InformingScience.org to request redistribution permission. gender, years in IT field, and management level. Of particular note, there was a significant difference in importance between male and female respondents for fourteen of the 42 skills in this study, particularly in proficiencies (females considered all but one of these skills more import ant than males), suggesting a gender effect. These results support previous studies that suggest nontechnical skills to be extremely impor- 
tant. But it differed from some studies in confirming that technical skills are also import ant for new IT hires, and which skills were most essential. This study sugge sts that academic programs should focus on enhancing these areas, concentrating on soft skills and those moretraditional areas of MIS, including databases, programming languages, and web skills.

Keywords: IS education, skill sets, IS professionals, survey, IS knowledge, IS curriculum

\section{Introduction}

Information technology (IT) professionals constitute one of the greatest cadres of knowledge workers in modern organizations today. Knowledge workers make up over one-half of the US workforce (Laudon \& Laudon, 2004) and include IT professionals such as programmers, analysts, database administrators, web designers, and network specialists. According to the "Tomorrow's Jobs" section of the 2006-2007 Occupational Outlook Handbook, five of the top dozen fastest growing occupations in the next decade are computer-related (U.S. Department of Labor, 2006). These facts notwithstanding, the IT field has long been plagued by high turnover and late project delivery dates. In a survey of 217 Chief Information Officers, $59 \%$ reported inadequate staffing levels and a high average turnover rate of $37 \%$ (Ware, 2005). One of the factors leading to these problems is that potential IT employees are inadequately prepared (e.g., Fang, Lee, \& Koh, 2005). When entry-level IT personnel do not possess the skills to effectively perform their duties, organizations face increased training demands, poor performance and efficiency, and increased turnover.

Understanding the skill sets required of entry-level personnel is critical to both organizations and the institutions that train them. For businesses, it is important from both training and hiring perspectives. Hiring properly trained individuals allows organizations to spend less time preparing new staff, thus more efficiently incorporat ing them into the workplace. For colleges, universities, and technical institutions, understanding the required skill sets is critical for curriculum maintenance and development.

This study empirically investigated which IT skills are most important for entry-level employees, using a sample of IT professionals from six companies (public and private) in the mid-South of the USA. Using a framework that divided skills into four major areas (IS Core Knowledge, Pro-

ficiencies, Business Expertise, and Personal Attributes), the present inquiry provided comparisons of skills among and within these areas using an empirical component not found in previous studies. The investigation also examined other aspects that may influence a respondent's choice of important skills, such as demographic factors, experience, and type of organization. The results offer a comprehensive, updated and statistically valid set of skills that will be of importance and use to both public and private organizations, as well as universities, colleges, and technical institutes.

\section{Background}

It is a common notion that IT graduates may lack the necessary skills to be successful in entrylevel IT positions (Cappel, 2001/2002; Fang et al., 2005; Noll \& Wilkins, 2002; Young \& Lee, 1997). Some studies report a widening gap between expected skill sets of new IT employees and those skills taught in educational inst itutions (Cappel, 2001/2002; Tang, Lee, \& Koh, 2000/2001). One reason for this predicament is the challenge of properly identifying entry-level skills required in the IT field. As a discipline, IT is constantly changing, with rapid advances in technology, shifting job descriptions, and an increasing number of diverse factors that influence job success. In addition, shifting industry pattems, greater compet ition, out sourcing, and globalization are blurring both job requirements and skills that are in demand (Lee \& Lee, 2006). 
Given the critical nature of understanding which skills are important, it is surprising that there is no established consensus regarding core skills required of IT professionals. Difficulties in gauging skill importance may stem from the fact that skill needs change as professionals establish their careers (e.g., Kovacs, Davis, Caputo, \& Turchek, 2005; Lee, Yen, Havelka, \& Koh, 2001). For example, Lee et al. (2001) reported that technical skills are more important during the earliest part of an IT career; non-technical skills become increasingly more important as careers develop. Thus, broad-based training of skill knowledge is required to encompass the needs of IT professionals throughout the longevity of their careers.

Various investigations have focused on ranking skill importance for entry-level IT professionals and the results have been equivocal. A number of studies found that personal characteristics, or "soft skills," are more important than technical skills for less experienced personnel (Fang et al., 2005; Kovacs et al., 2005; Young, 1996). For example, Cappel (2001/2002) found that IT professionals rated soft skills as more important than technical skills for new hires and suggested that the "greatest room for improvement" in new IS graduates is in the area of non-technical skills (p. 81). In contrast, several investigations have suggested that technical skills are more imperative (Koong, Liu, \& Liu, 2002; Lee et al., 2001; Todd, McKeen, \& Gallupe, 1995). For example, Lee and colleagues (2001) found that junior IS professionals, as compared to more experienced employees, are more likely assigned to activities that aretechnical in nature. Additional findings of previous investigations indicate that intern experience, as well as technical skills, augments the hiring qualifications of entry-level IT professionals (Fang et al., 2005; Lee et al., 2001).

The ambiguity concerning skill import ance for entry-level personnel may stem from a hist ory of needed, but methodologically diverse, studies. Dat a collection techniques have included examining newspaper advertisements of employers (Todd et al., 1995), job postings on Fortune 500 company web sites (Lee \& Lee, 2006), internet job databases such as monster.com (Koong et al., 2002), as well as using a variety of surveys that elicited responses directly from employers and/or educators (e.g., Gill \& Hu, 1998; Leitheiser, 1992; T ang et al., 2000/2001; Young \& Lee, 1997).

The variations in findings among studies may also be due to different classification schemes used to examine the importance of skills and knowledge areas of IT professionals. For example, Lee et al. (2001) included IT activities (knowledge areas and proficiencies) and professional skills (business skills, and interpersonal skills and traits). Cappel (2001/2002) included programming language s, technical knowledge areas, proficiencies, and personal qualities. Similarly, Fang et al. (2005) used personal skills and traits, core IT skills (technical knowledge and proficiencies), and organizat ional knowledge. In addition to such studies, several professional organizations have addressed skills, particularly for entry-level personnel. The most recent model, IS 2002, was developed jointly by the Association of Computing Machinery (ACM), Association of Information Systems (AIS), and Association of Information Technology Professionals (AITP) (Gorgone et al., 2002). This model contends that entry-level personnel should possess skills in business fundamentals; interpersonal, communications, and team skills; analytical and criticalthinking skills; and technology skills. Thus, the various taxonomies used in previous investigat ions may have resulted in diverse findings among studies. This fact lead to an import ant goal of the current investigation: to determine a statistically significant ordering of skills.

\section{A New Investigation}

There are four primary reasons why a new investigation is important to both the professional and academic communities. First, technology is changing rapidly, and staying informed regarding the needed skills of IT professionals is a continuous process. Second, results from previous studies have been mixed. Third, this investigation concentrates solely on the skill sets required of entrylevel recruits, a population that may require different skills than other IT professionals (Lee et al., 
2001). Finally, the current study obtained the perceptions of IT professionals in the field, which are vital to determining the most important skills needed by entry-level personnel. Past investigations have interviewed other groups (such as recruiters, educators, or students) regarding the import ance of entry-level skills (e.g., Fang et al., 2005; Tang et al., 2000/2001; Turner, 2004; Young $\&$ Lee, 1997). Some of these participants may not have had the background, or experience, of IT practitioners as to which skills are most important.

\section{Research Questions}

The purpose of this study was to determine which skills were most important for entry-level IT personnel based on the perceptions of IT professionals in the field. A well-rounded set of important skills was expected to emerge, since the IT professionals surveyed had different and diverse backgrounds. In addition to establishing a hierarchy of skills, another motivation of this investigation was to determine whether there were areas (e.g., soft skills vs. technical skills) that were more critical than others to early career success. An understanding of skill importance would prove extremely useful to both organizations and educational institutions. This leads to the first three research questions:

1. What skills are most important for entry-level IT professionals?

2. What skills within each area (IS Core Knowledge, T echnical Proficiencies, Business Expertise, and Personal Attributes) are most important?

3. What areas are most important for entry-level IT personnel?

There are several important factors that may affect how current IT professionals rate skill importance. Upper IT managers may consider certain types of soft skills more import ant than technical proficiencies; thus, the management level of the respondent may significantly affect ordering of skills. Demographic characteristics, such as age, education, gender, or years in the IT field, may also influence the ordering of skills by respondents, as well as the type of business (or industry) where they are employed. This study will test the influence of these factors in determining which skills are most important for entry-level employees. This leads to three additional research questions:

4. Do demographic factors of respondents influence their perceptions of skill importance?

5. Does the managerial level of respondents influence their perceptions of skill importance?

6. Does the type of organization influence perceptions of skill importance?

\section{Methodology}

\section{Questionnaire}

A questionnaire was developed using standard survey development techniques (Churchill, 1979; Nunnally, 1967; Straub, 1989). An exhaustive review of the literature was performed, and IT professionals in various business disciplines were consulted regarding the skill questions listed in the prototype survey. The literat ure review revealed that several of the studies used similar areas and skills in their research instruments. For example, the majority of studies included a personal skills area that contained communication (written and oral) skills, team skills, and critical and creative thinking skills. All investigations included programming abilities and other proficiencies. Overall, the review indicated that skills required of IT professionals are generally placed into four classification areas: IS core knowledge, proficiencies, business expertise, and personal traits or characteristics. 
The literature review yielded a comprehensive list of skills that were collated and examined by several colleagues and IT practitioners for input. A preliminary questionnaire was developed and given to seven IT workers from three industries (retail, insurance, and consulting). Their input resulted in minor changes, which lead to a pilot test that was administered to twenty IT professionals. Following another round of modifications, the final form of the survey included 42 skill questions: fifteen in the area of IS Core Knowledge, fourt een Proficiencies, seven in Business Expertise, and six in Personal Attributes (the survey instrument items are contained in the Appendix).

The survey was conducted in an on-line format. For each of the 42 skill questions, respondents were instructed to indicate the importance of the skill on a seven-point Likert scale with anchors at 1 (Not Important) and 7 (Very Important). In addition, each question had a separate response choice of "Don't Know". The research instrument also included demographic inquiries relat ing to the respondents and their organizations.

\section{Organizations}

Six organizations from the mid-South of the USA, including two Fortune-500 firms, participated in the study. The IT departments from five large companies and one medium-sized university (over 12,000 students) were contacted and solicited for inclusion. Organizations represented included those that recruit MIS/CS majors at several universities in the region. Industry segments (with the percentage of respondents in parentheses) included retail (67\%), insurance (5\%), telecommunications $(2 \%)$, logistics $(5 \%)$, IT consulting $(9 \%)$, and education $(12 \%)$. The organizations averaged $\$ 3.6$ billion in revenues. In order to obtain respondents for the study, initial contact was made with high-ranking IT management personnel within each company to gain their involvement and consent. A senior-level IT manager from each organization served as the lead contact person who aided in the recruitment of survey respondents. These managers sent the URL for the survey to respondents within their company. Thus, this method of soliciting respondents resulted in a convenience sample. Convenience sampling has been shown to be an effective means of obtaining survey respondents with the desired backgrounds or points of view. Such convenience samples are not uncommon in IS research (e.g., Baroudi \& Ginzberg, 1986; Couger, Higgins, \& McIntyre, 1993; Igbaria \& Baruoudi, 1993; Gupta, Guimaraes, \& Raghunathan, 1992; McMurtrey, Grover, Teng, \& Lightner, 2002; Santana \& Robey, 1995).

\section{Respondents}

A total of 159 respondents completed the questionnaire. Surveys from six respondents were excluded because of incomplete data, resulting in a total of 153 usable surveys. All respondents were working IT professionals, including CIOs, programmers, analysts, IT project leaders or team members, and support staff (e.g., help desk, software support). The actual response rate could not be determined, since IT managers did not keep a record of the number of IT professionals to whom the URL for the survey was forwarded.

The majority of respondents were male (67\%) with an average of 14.6 years in the IT field. Eighty-four percent had at least a Bachelor's degree, while $20 \%$ held a graduate degree. The age of the participants was predominantly between $30-49$ years $(35 \%$ in their $30 \mathrm{~s} ; 28 \%$ in their $40 \mathrm{~s})$; most of the remaining were in their $50 \mathrm{~s}(19 \%)$ or $20 \mathrm{~s}(17 \%)$. The majority of respondents $(52 \%)$ were IT professionals with no direct subordinates. Forty-eight percent were IT managers, including CIO/CT Os (2.5\%), middle IT managers (23\%), and supervisors or team leaders (20\%). Job functions varied, although $38 \%$ reported programming (development and maintenance) as one of their primary tasks (each respondent was allowed to include up to three job functions). Other common functions included analyst (22\%), project leader (9\%), internal customer support $(6 \%)$, 
and database or network support (both 3\%). Eleven percent chose "Other", and most of those described themselves as programmer/analysts. Table 1 shows demographic characteristics of respondents.

Table 1: Demographic Characte ristics of Respon dents

\begin{tabular}{|c|c|c|c|}
\hline & & Number & Percentage \\
\hline \multicolumn{4}{|l|}{ Gender: } \\
\hline Male & & 99 & 64.71 \\
\hline Female & & 50 & 32.68 \\
\hline \multirow[t]{2}{*}{$\mathrm{NR}$} & & 4 & 2.61 \\
\hline & Total & 153 & 100.00 \\
\hline \multicolumn{4}{|l|}{ Age: } \\
\hline $20-29$ & & 26 & 16.99 \\
\hline $30-39$ & & 53 & 34.64 \\
\hline $40-49$ & & 42 & 27.45 \\
\hline $50-59$ & & 27 & 17.65 \\
\hline $60+$ & & 2 & 1.31 \\
\hline \multirow[t]{2}{*}{ NR } & & 3 & 1.96 \\
\hline & Total & 153 & 100.00 \\
\hline \multicolumn{4}{|l|}{ Highest Degree Earned } \\
\hline High school & & 1 & 0.65 \\
\hline Some college & & 18 & 11.76 \\
\hline \multicolumn{2}{|c|}{ Assoc/tech degree (2-yr) } & 6 & 3.92 \\
\hline \multicolumn{2}{|l|}{ Undergraduate deg ree } & 91 & 59.48 \\
\hline \multicolumn{2}{|l|}{ Some graduate school } & 5 & 3.27 \\
\hline Graduate degree & & 31 & 20.26 \\
\hline \multirow[t]{2}{*}{ NR } & & 1 & 0.65 \\
\hline & Total & 153 & 100.00 \\
\hline \multicolumn{4}{|l|}{ Organizational Level } \\
\hline CIO/CTO/Executive & & 4 & 2.61 \\
\hline \multicolumn{2}{|c|}{ Director/Middle Management } & 36 & 23.53 \\
\hline \multicolumn{2}{|c|}{ Supervisory/Team Leader } & 30 & 19.61 \\
\hline \multicolumn{2}{|c|}{ Professional (no subordinates) } & 77 & 50.33 \\
\hline \multirow[t]{2}{*}{ Other } & & 6 & 3.92 \\
\hline & Total & 153 & 100.00 \\
\hline \multicolumn{4}{|c|}{\begin{tabular}{|l|l} 
Job Function:* & \\
\end{tabular}} \\
\hline \multicolumn{2}{|c|}{ Development programmer } & 79 & 23.94 \\
\hline \multicolumn{2}{|c|}{ Maintenance programmer } & 48 & 14.55 \\
\hline Development analyst & & 45 & 13.64 \\
\hline Other & & 37 & 11.21 \\
\hline Project leader & & 30 & 9.09 \\
\hline Maintenance analyst & & 25 & 7.58 \\
\hline \multicolumn{2}{|c|}{ Customer support (internal) } & 20 & 6.06 \\
\hline Project team member & & 12 & 3.64 \\
\hline Database support & & 10 & 3.03 \\
\hline Network support & & 10 & 3.03 \\
\hline \multicolumn{2}{|c|}{ Customer support (external) } & 9 & 2.73 \\
\hline \multirow[t]{2}{*}{ Web/Internet support } & & 5 & 1.52 \\
\hline & Total* & 330 & 100.00 \\
\hline \multicolumn{4}{|c|}{$*$ multiple entries allowed } \\
\hline $\mathrm{NR}=$ No Response & & & \\
\hline
\end{tabular}




\section{Statistical Analyses}

The first research question concerned which skills were most important to entry level professionals. Each of the 42 skills was ranked in sequence by their raw means (Table 2). Subsequently, a statistically significant ordering of skills was determined by conducting a series of pairwise $t$-tests using the following formula (Anderson, Sweeney, \& Williams, 1996):

$$
t=\left(x_{1}-x_{2}\right) \div \sqrt{\left(s_{1}{ }^{2} \div n_{1}\right)+\left(s_{2}{ }^{2} \div n_{2}\right)}
$$

where $\mathrm{x}_{1}$ and $\mathrm{x}_{2}$ are means, $\mathrm{s}_{1}$ and $\mathrm{s}_{2}$ are standard deviations, and $\mathrm{n}_{1}$ and $\mathrm{n}_{2}$ are sample sizes.

Table 2: Summary Data Analysis

Key: B E-B usiness Expertise, IS-IS Core Knowledge. PA-Personal Attributes, PR-Proficiencies

\begin{tabular}{|c|c|c|c|c|}
\hline Tier & $\begin{array}{l}\text { O ve rall } \\
\text { Rank }\end{array}$ & $\begin{array}{l}\text { Skill } \\
\text { Area }\end{array}$ & Skill Item & $\begin{array}{c}\text { Response } \\
\text { Ave rage }\end{array}$ \\
\hline \multirow{6}{*}{1} & 1 & PA & Problem solving skills & 6.69 \\
\hline & 2 & PA & Critical thinking skills & 6.59 \\
\hline & 3 & PA & Team skills & 6.52 \\
\hline & 4 & PA & Communication skills (oral) & 6.22 \\
\hline & 5 & PA & Creative thinking skills & 6.18 \\
\hline & 6 & PA & Communication skills (written) & 6.07 \\
\hline \multirow{6}{*}{2} & 7 & IS & Database Query Language (SQL): & 5.51 \\
\hline & 8 & BE & Ethics and Privacy Issues & 5.46 \\
\hline & 9 & IS & High level languages & 5.39 \\
\hline & 10 & IS & Object-oriented languages & 5.11 \\
\hline & 11 & IS & Database design/development & 4.98 \\
\hline & 12 & PR & Client-server database & 4.98 \\
\hline \multirow{6}{*}{3} & 13 & BE & Security Issues & 4.93 \\
\hline & 14 & IS & Web development languages & 4.82 \\
\hline & 15 & PR & Office Software & 4.53 \\
\hline & 16 & BE & Business Environment & 4.52 \\
\hline & 17 & IS & Web design/publication languages & 4.51 \\
\hline & 18 & BE & Organizational Knowledge & 4.49 \\
\hline \multirow{6}{*}{4} & 19 & IS & Object-oriented concepts & 4.47 \\
\hline & 20 & IS & Project management & 4.43 \\
\hline & 21 & PR & Spreadsheets & 4.41 \\
\hline & 22 & BE & Business Functions & 4.39 \\
\hline & 23 & IS & Mini/Mainframe OS knowledge & 4.11 \\
\hline & 24 & BE & E-Commerce & 4.08 \\
\hline \multirow{6}{*}{5} & 25 & IS & OS knowledge & 3.97 \\
\hline & 26 & IS & Hardware & 3.84 \\
\hline & 27 & IS & Network topologies \& protocols & 3.70 \\
\hline & 28 & BE & Globalization Issues & 3.70 \\
\hline & 29 & PR & Project management tools & 3.62 \\
\hline & 30 & PR & Data warehouse/data mart & 3.61 \\
\hline \multirow[t]{3}{*}{6} & 31 & IS & Network hardware & 3.45 \\
\hline & 32 & PR & Personal database & 3.43 \\
\hline & 33 & IS & Mobile or wireless networks & 3.11 \\
\hline
\end{tabular}




\begin{tabular}{|c|c|c|l|c|}
\hline & 34 & PR & Web design with editors & 3.00 \\
& 35 & IS & CASE tools & 2.57 \\
& 36 & PR & Decision Support Systems (DSS) & 2.534 \\
\hline \multirow{6}{*}{7} & 37 & PR & ERP systems & 2.53 \\
& 38 & PR & Group Support Systems (GSS) & 2.51 \\
& 39 & PR & Statistical Packages & 2.26 \\
& 40 & PR & Simulation/optimization tools & 2.25 \\
& 41 & PR & AI/Expert Systems & 2.24 \\
& 42 & PR & GIS systems & 2.07
\end{tabular}

This statistical technique is appropriate because our sample consisted of just one group. Each survey respondent ranked each of the 42 skills (from 1-7), providing an ordering which can be independently compared. Were the items to come from two (or more) populations, the problems associated with using multiplet-tests and in particular the increasing probability of committing a Type 1 error would be present. When testing means from multiple samples, researchers frequently run an ANOVA for global significance, followed by post-hoc testing (such as Fisher's LSD, T ukey's HSD, or Scheffe's test) which tests differences in specific individual means. The structure of this study, however, with its single population, allows an independent comparison of pairs of means to be tested (Anderson et al., 1996). Each $t$-test is independent of others, which would not be the case with multiple samples.

Prior to conducting the pairwise $t$-tests, several of the means of the fifteen skill items contained in the IS Core Knowledge area were combined, as the skills were similar in characteristics. For example, the means of the two Operating System knowledge skills (OS Knowledge and Mainframe OS Knowledge) were combined, as were the means of two Database knowledge skills (Database Design and Development and Database Query Languages). This assimilation resulted in nine skill groups. The refined set of means from the IS Core Knowledge area, along with the skill means from the other three areas, were then re-ranked and pairwise $t$-tests were performed on the top twelve skills (Table 3).

Table 3: Top Twelve Skills

\begin{tabular}{|c|l|l|c|c|l|}
\hline Rank & \multicolumn{1}{|c|}{ Skill } & \multicolumn{1}{|c|}{ Area } & Mean & t-value* & $\begin{array}{c}\text { Sig. } \\
\text { More Imp. } \\
\text { Than }\end{array}$ \\
\hline 1 & Problem Solving & Personal Attributes & 6.69 & 4.24 & Oral Comm. \\
2 & Critical Thinking & Personal Attributes & 6.59 & 3.30 & Oral Comm. \\
3 & Team Skills & Personal Attributes & 6.52 & 2.64 & Oral Comm. \\
4 & Oral Comm. & Personal Attributes & 6.22 & 5.69 & Ethics/Privacy \\
5 & Creative Thinking & Personal Attributes & 6.18 & 5.34 & Ethics/Privacy \\
6 & Written Comm. & Personal Attributes & 6.07 & 4.51 & Ethics/Privacy \\
7 & Ethics/Privacy & Business Expertise & 5.46 & 3.25 & C-S Databases \\
8 & Database (2 items) & IS Core Knowledge & 5.24 & 1.97 & Languages \\
9 & C-S Databases & Profici ency & 4.98 & N/A & N/A \\
10 & Languages (4 items) & IS Core Knowledge & 4.96 & N/A & N/A \\
11 & Security & Business Expertise & 4.93 & N/A & N/A \\
12 & Object-Oriented (2 items) & IS Core Knowledge & 4.80 & N/A & N/A \\
\hline \multicolumn{2}{|l|}{$*$ Significant at $p<.05$. For significance, the $t$-value must be greater than 1.96 } \\
\hline
\end{tabular}


The significance level was set at $\mathrm{p}<.05$, where a $t$-result greater than 1.96 was considered significant. In order to test for significance, the mean of the top ranked skill was first compared to the mean of the skill ranked directly below (second highest mean). If the mean difference was not significant, the highest ranked skill was then compared to the next highest ranked skill (third highest mean). If a significant difference was found, all other means ranked lower than the third highest mean were also considered significantly different from the highest ranked mean, and pairwise testing resumed with the next skill on the list. This procedure was continued until comparisons were made among all remaining means.

In order to answer the second and third research questions, pairwise $t$-tests were used to compare the means within the four classification areas (IS Core Knowledge, Proficiencies, Business Expertise, and Personal Attributes), and to compare the overall means of the four areas. The remaining research questions (4-6) were answered by examining the effects of various demographic variables on the perceptions of skill need using regression analysis.

\section{Results}

\section{Most Important Skills - Research Question 1}

\section{Ranking of raw means}

The 42 skills were ranked in sequence by their means and were evenly distributed into seven tiers. Means ranged from a high of 6.69 (out of 7.0) to a low of 2.07. As shown in Table 2, the top tier was entirely comprised of Personal Attributes. Problem Solving was the highest ranked skill (6.69), followed by Critical Thinking (6.59), then Team Skills (6.52). Oral Communication (6.22), Written Communication (6.07), and Creative Thinking (6.18) skills rounded out the top tier.

The majority of skills in the second tier were related to database knowledge, including Structured Query Language (5.51), Database Design and Development (4.98), and Client-Server Databases (4.98). The Ethics/Privacy item was also ranked highly (5.56), as well as knowledge of both High-level (5.39) and Object-Oriented (5.11) languages. At the other end of the spectrum, skills comprising the bottom tier included knowledge of ERP systems (2.53), statistical tool proficiency (2.26), and knowledge of AI and/or Expert Systems (2.24). The lowest rated skill in the survey was knowledge of Geographical Information Systems (2.07).

\section{Significant ordering of skills}

After examining the raw means, a statistically significant ordering of skills was determined using a series of pairwise $t$-analyses. Of the top twelve skills, Problem Solving, Critical Thinking, and Team Skills were rated highest, respectively, and the perception of the importance of these skills were not significantly different from each other. However, these skills were found to be significantly more important than Oral Communication skills. Similarly, respondents found Oral Communication, Creative Thinking, and Written skills significantly more important than Ethics/Privacy. This latter skill was deemed significantly more import ant than the combined Database (SQL and Design/Development) skill from the IS Core Knowledge Area. Finally, the Database skill was determined to be significantly more import ant than the Languages item, according to respondents. Table 3 shows the results. 


\section{Comparisons of Skills within Areas - Research Question}

\section{IS core knowledge}

As mentioned previously, the IS Core Knowledge area initially contained fifteen skills. Because several of the skills contained similar characteristics, the means of these skills were combined prior to performing statistical analyses. This assimilation resulted in nine skill groups. Most groups consisted of two individual skills, one consisted of four (Languages), and one (Mobile/Wireless) was stand-alone.

Table 4 presents the IS Core Knowledge area results. Database (with its two items) had the highest mean (5.24), followed by Languages (4.96), Object-Oriented Knowledge (4.80), and Web Knowledge (4.67). The two lowest means in this area were Projects (3.51) and Mobile/Wireless (3.08). Pairwise $t$-tests were conducted to examine the mean difference between the Database and Language groups, and Dat abase with all other groups thereafter. Dat abase was perceived by respondents to be significantly more important than Languages, as well as all remaining groups. Languages, however, were not significantly more important than Object-Oriented Knowledge, but were found to be significantly more important than Web Knowledge. Object-Oriented Knowledge and Web Knowledge were not perceived as significantly different from each other.

Table 4: IS Core Knowle dge

\begin{tabular}{|c|l|c|c|c|c|c|l|}
\hline Rank & \multicolumn{1}{|c|}{ Skill } & $\begin{array}{c}\text { Number } \\
\text { of } \\
\text { Ques tions }\end{array}$ & n & Mean & SD & $\begin{array}{c}\text { t- } \\
\text { value* }\end{array}$ & $\begin{array}{c}\text { Sig. } \\
\text { More } \\
\text { Imp. } \\
\text { Than }\end{array}$ \\
\hline 1 & Database & 2 & 153 & 5.24 & 1.56 & 1.97 & Languages \\
2 & Languages & 4 & 152 & 4.96 & 1.53 & 2.02 & Web \\
3 & Object-Oriented Know. & 2 & 152 & 4.80 & 1.57 & 5.38 & OS \\
4 & Web Knowledge & 2 & 151 & 4.67 & 1.70 & 4.34 & OS \\
5 & Operating Systems & 2 & 153 & 4.05 & 1.40 & 2.97 & HW \\
6 & Hardware & 2 & 153 & 3.65 & 1.34 & 4.15 & Mobile \\
7 & Networks & 2 & 153 & 3.58 & 1.37 & 3.60 & Mobile \\
8 & Projects & 2 & 152 & 3.51 & 1.31 & 3.14 & Mobile \\
9 & Mobile/Wireless & 1 & 153 & 3.08 & 1.47 & N/A & N/A \\
\hline
\end{tabular}

\section{Technical proficiencies}

There were fourteen different Technical Proficiencies which were compared in the same manner. Within this area, Client-Server Database was rated highest (4.98) by respondents, followed by Office Software (4.53), Spreadsheets (4.41), Project Management Tools (3.62), etc. Those skills ranked lowest were Statistical (2.26) and Simulation Packages (2.25), Artificial Intelligence/Expert Systems (2.24), and Geographical Information Systems (2.07).

Results of the pairwise $t$-tests indicated that Client-Server database skills were perceived to be significantly more important than Office Software, while this latter skill, along with Spreadsheets, was found to be significantly more important than Project Management Tools. Project Management Tools were perceived by respondents to be significantly more import ant than being skilled with Web Editors. Table 5 presents the results. 
Table 5: Technical Proficien cies

\begin{tabular}{|c|l|c|c|c|c|l|}
\hline Rank & \multicolumn{1}{|c|}{ Proficiency } & n & Mean & SD & t-value* & $\begin{array}{c}\text { Sig. } \\
\text { More Imp. } \\
\text { Than }\end{array}$ \\
\hline 1 & Database (C-S) & 150 & 4.98 & 1.66 & 3.06 & Office SW \\
2 & Office SW & 150 & 4.53 & 1.53 & 6.33 & Proj. Mgt. \\
3 & Spreadsheets & 149 & 4.41 & 1.51 & 5.48 & Proj. Mgt. \\
4 & Proj. Mgt. Tools & 149 & 3.62 & 1.55 & 4.34 & Web Editors \\
5 & Data Warehouse & 147 & 3.61 & 1.73 & 4.09 & Web Editors \\
6 & Database (Personal) & 150 & 3.43 & 1.53 & 2.98 & Web Editors \\
7 & Web Editors & 150 & 3.00 & 1.55 & 3.17 & DSS \\
8 & DSS & 148 & 2.53 & 1.67 & 2.03 & AI/ES \\
9 & ERP & 146 & 2.53 & 1.62 & 1.99 & AI/ES \\
10 & GSS & 148 & 2.51 & 1.43 & 3.19 & GI S \\
11 & Statistical Packages & 149 & 2.26 & 1.53 & N/A & None \\
12 & Simulation Packages & 147 & 2.25 & 1.60 & N/A & None \\
13 & AI/Expert Systems & 149 & 2.24 & 1.40 & N/A & None \\
14 & GI S & 149 & 2.07 & 1.39 & N/A & N/A \\
\hline \multicolumn{7}{|c|}{ *Significant at p $<.05$. For significance, the -value must be greater than 1.96} \\
\hline
\end{tabular}

\section{Business expertise}

There were seven skills in this area. Ethics/Privacy was rated most important (5.46), followed by Security (4.93), understanding the Business Environment (4.52), and Organizat ional Knowledge (4.49). E-Commerce and Globalization Issues were rated the lowest (4.08 and 3.70, respectively). Statistical analyses revealed that Ethics/Privacy was perceived to be significantly more important than Security, and this latter skill was significantly more important than Business Environment. Respondents perceived Business Environment, Organizational Knowledge, and Business Functions to be equally import ant as there were no significant differences among these skills. However, all three were found to be significantly more important than E-Commerce. The results are presented in Table 6.

Table 6: Business Expertise Areas

\begin{tabular}{|c|l|c|c|c|c|l|}
\hline Rank & \multicolumn{1}{|c|}{ Area } & $\mathbf{n}$ & Mean & SD & $\boldsymbol{t}$-value* & $\begin{array}{c}\text { Sig. } \\
\text { More Imp. } \\
\text { Than }\end{array}$ \\
\hline 1 & Ethics/Privacy & 145 & 5.46 & 1.68 & 3.48 & Security \\
2 & Security & 145 & 4.93 & 4.61 & 2.71 & Bus. Environ. \\
3 & Business Environment & 145 & 4.52 & 1.59 & 2.92 & E-Commerce \\
4 & Organizational Know. & 144 & 4.49 & 1.76 & 2.60 & E-Commerce \\
5 & Business Functions & 144 & 4.39 & 1.64 & 2.00 & E-Commerce \\
6 & E-Commerce & 145 & 4.08 & 1.73 & 2.56 & Global Issue s \\
7 & Globalization Issues & 145 & 3.70 & 1.56 & N/A & N/A \\
\hline \multicolumn{7}{|l}{ * Significant at $\mathrm{p}<.05$. For significance, the $t$-value must be greater than 1.96 } \\
\hline
\end{tabular}

\section{Personal attributes}

The final area consisted of skills relating to Personal Attributes. The means for all six skills were above 6.0 (with 7.0 the maximum), among the highest rated skills in the survey. Problem Solving 
(6.69), Critical Thinking (6.59), and Team Skills (6.52) were rated by respondents as the top three skills in this area and were not perceived to be significantly different from each other. All three, however, were found to be significantly more important than Oral Communications. The last three skills, Oral Communications (6.22), Creative Thinking (6.18), and Written Communications (6.07), were not significantly different from each other. The results are presented in Table 7.

Table 7: Personal Attributes

\begin{tabular}{|c|l|c|c|c|c|l|}
\hline Rank & \multicolumn{1}{|c|}{ Skill } & $\mathbf{n}$ & Me an & SD & $\boldsymbol{t}$-value* & $\begin{array}{c}\text { Sig. } \\
\text { More Imp. } \\
\text { Th an }\end{array}$ \\
\hline 1 & Problem Solving & 143 & 6.69 & 0.70 & 4.24 & Oral Comm. \\
2 & Critical Thinking & 143 & 6.59 & 0.82 & 3.30 & Oral Comm. \\
3 & Team Skills & 142 & 6.52 & 0.86 & 2.64 & Oral Comm. \\
4 & Oral Communications & 143 & 6.22 & 1.05 & N/A & None \\
5 & Creative Thinking & 142 & 6.18 & 1.10 & N/A & None \\
6 & Written Communications & 143 & 6.07 & 1.12 & N/A & N/A \\
\hline \multicolumn{7}{|l|}{ *ignificant at $\mathrm{p}<.05$. For significance, the $t$-value must be greater than 1.96 } \\
\hline
\end{tabular}

\section{Area Comparisons - Research Question 3}

To determine which of the four areas (IS Core Knowledge, Skills and Proficiencies, Business Expertise, and Personal Attributes) were considered most important by respondents, an overall mean was calculated for each area. The highest ranked skill area was Personal Attributes (6.38), followed by Business Expertise (4.51), IS Core Knowledge (4.26), and Technical Proficiencies (3.15). Statistical results indicated that the Personal Attributes area was significantly more important than all others. Business Expertise was significantly more important than the IS Core Knowledge and Proficiencies areas; IS Core Knowledge was found to be significantly more important than Technical Proficiencies. Results are shown in Table 8.

Table 8: Are a Comparisons

\begin{tabular}{|c|c|c|c|c|c|c|}
\hline Rank & Area & $\mathbf{N}$ & Me an & SD & $t$-value* & $\begin{array}{c}\text { Sig. } \\
\text { More Imp. } \\
\text { Than }\end{array}$ \\
\hline 1 & Personal Attributes & 143 & 6.38 & 0.76 & 15.61 & Business Expertise \\
\hline 2 & Business Expertise & 145 & 4.51 & 1.30 & 1.98 & IS Core Knowledge \\
\hline 3 & IS Core Knowledge & 153 & 4.26 & 1.07 & 9.35 & Proficiencies \\
\hline 4 & $\begin{array}{l}\text { Technical Proficien- } \\
\text { cies }\end{array}$ & 150 & 3.15 & 1.08 & N/A & $\mathrm{N} / \mathrm{A}$ \\
\hline
\end{tabular}

\section{Other Factors Influencing Skills - Research Questions 4-6}

Regression analyses were utilized (using $\mathrm{p}<.05$ ) to determine if any demographic factors (i.e., management level, age, gender, years in IT field, education, and place of employment) had a significant effect on the selection of skill importance. Most of the significant findings accounted for a small variation in skill selection. Only one factor, education, was not significant. Thus, the level of education of respondents had no effect on skill selection. In the following paragraphs, $\mathrm{R}^{2}$ is converted to a percentage. 


\section{Age}

Age significantly influenced the selection of four skills: Mobile/Wireless knowledge (2\%), Office Software (2\%), Organizational Knowledge (4\%), and Globalization Issues (3\%). Older respondents, in contrast to younger respondents, considered Mobile/Wireless skills as more important, while Office Soft ware, Organizational Knowledge, and Globalization Issues were considered as less important skills.

\section{Gender}

Gender had a significant influence on the selection of fourteen skills. Females, versus their male counterparts, considered the following thirteen skills as more important: OO Knowledge (4\%), Web Knowledge (4\%), Languages (3\%), GSS (3\%), Data Warehousing (4\%), ERP (5\%), Project Tools (4\%), Simulation Packages (7\%), St at istical Packages (8\%), Business Functions (4\%), Business Environment (3\%), E-Commerce (4\%), and Globalization (6\%). The one skill that females thought less important was Project Knowledge (4\%).

\section{Years in IT field}

The number of years spent in the IT field influenced the selection of four skills. Less experienced respondents, in comparison to more experienced staff, believed the following skills as more important: Office Software (2\%), Organizational knowledge (11\%), Business Functions (3\%), and Business Environment (5.1\%).

\section{Management level}

Respondents reported their level of management as CIO/CT O/ Execut ive, Director/Middle Management, Supervisory/T eam Leader, Professional (no subordinates), or Other. The level of the IT professional had a significant effect on the selection of only one skill, Creative Thinking (3\%). Upper managers perceived Creative Thinking as a less important skill.

\section{Organization}

The type of organization where the respondents were employed was the final factor examined. Organization type influenced the perceived importance of eleven skills. The university and retailer IT staffs were similar in their assessments of several skills. Both, in contrast to the respondents from the other organizations, considered the following skills as more important: Database, Languages, Client-Server Database, and Business Functions. In addition, the university staff valued Object-Oriented Knowledge, Networks, and Business Environment highly, whereas the retailer staff considered Web Editors as more important, compared to the other organizations. The other four firms (insurance, telecommunications, logistics, and IT consulting) perceived only one skill, Web Editors, as more import ant than the other organizations.

In regard to those skills considered significantly less important, Hardware and GSS were perceived similarly by both the university and retailer staffs. In addition, the retailer considered Personal Databases as less important, in contrast to the other organizations.

\section{Discussion}

The goal of this study was to determine which skills current IT professionals deem as most important for new, entry-level personnel. Results of this investigation may provide business organizations the opport unity to establish or refine their entry-leveltraining efforts. This investigation 
also affords educational institutions the opportunity to examine and revise curriculum to better support the needs of the business community. This study confirms results of previous investigations, as well as provides new findings for consideration.

\section{Non-Technical Skills Are Most Important}

The results of this investigation showed that, overall, IT professionals viewed soft skills as more important than technical skills for the successful integration of entry-level employees. This finding supports those found in previous studies (Fang et al., 2005; Kovacs et al., 2005; Young, 1996). Of the 42 skills, the top seven were non-technical in nat ure and six of these were Personal Attributes. The seventh, Ethics/Privacy, reflects an increasing concern among professionals in modern-day organizations to maintain corporate integrity. The fact that soft skills dominated the rankings clearly illustrates the importance placed on individual traits and characteristics by potential employers. Abilities such as problem solving, critical thinking, and communications skills allow new personnel to more easily int egrate technical skills on the job. Additionally, nontechnical skills tend to apply to all IT jobs (Kovacs et al., 2005), even though the job descriptions for such posts tend to be position-specific.

Within the Personal Attributes area, respondents demonstrated their preference for entry-level personnel skilled in problem solving, critical thinking, and team skills. There was no difference in respondents' perceptions of the importance of these traits. Allthree were found to be significantly more important than both oral and written communications, and creative thinking. This finding suggests that strong analysis and team-building skills continue to be of paramount importance in addressing the complexities facing IT departments today. Furthermore, many items pertaining to Business Expertise were also ranked highly. This shows that knowing company products, customers, and history, as well as functional area operations are also imperat ive to the success of new staff. Surprisingly, the Globalization Issues skill was least important, despite the fact that some of the organizations had international operations. Interestingly, being skilled in Ecommerce activities was also regarded as less important by respondents. This finding may reflect the notion that, although the Int ernet has permeated corporate life, these skills do not represent the integral components required to ensure the efficient day-to-day operation of many organizations. Thus, while the concepts of globalization and E-commerce are certainly important to the expansion of growing organizations, results from this study showed that entry-level personnel need not necessarily be proficient in these skills for their successful immersion into a firm.

\section{Technical Skills: Are They Still Important?}

Although "soft" skills emerged as the top-ranked abilities by respondents, this study also shows that technical skills cont inue to be important for entry-level professionals. Several technical skills were rated highly by IT professionals, including Database, Languages, Object-Oriented Knowledge, Web Knowledge, Operating Systems, etc., consistent with the results of previous investigations (e.g., Koong et al., 2002; Todd et al. 1995). Thus, these findings suggest that IT professionals believe that such "hard" skills remain vital in modern IT departments. Conversely, skills pertaining to ERP, AI/Expert Systems, Statistical and Simulation Packages, CASE Tools, and GIS were ranked among the lowest in the study. This finding may reflect budgetary constraints concerning the implementation of these systems or, perhaps, these skills were not perceived as essential for entry-level personnel. 


\section{Summary of Area Comparisons}

An examination of the four skill classifications indicated that current IT pract it ioners believe that the Personal Attributes area was the most important for entry-level personnel. The second most important was Business Expertise, which is also non-technical in nature. Thus, technical proficiencies and specific core concepts, which are common courses in academic curricula and training programs, may be overemphasized. These findings suggest that, in order to prepare graduates to enter the workforce, training efforts should focus more on soft skills than has previously been the case. Universities and othertraining facilities should collaborate with IT professionals in offering students internships and providing opportunities for inclusion in professional organizations. Such experiences may afford students the prospect of improving soft skills such as teambuilding and written and oral communications.

Although the Technical Proficiencies and IS Core Knowledge areas were significantly lower in importance than Personal Attributes and Business Expertise, this finding does not indicate that all skills in these areas were perceived as unimportant. Moreover, several technical skills were rated highly. One reason for the lower group means in these areas is that respondents did not consider some of the skills to be highly import ant. These perceptions brought down the overall average for both areas. For example, seven of the fourteen Proficiencies had means below 2.60 (DSS, ERP, GSS, Statistics, Simulation, AI/ES, and GIS), significantly reducing its overall average.

\section{Demographics and Other Factors}

Surprisingly, few previous studies have considered the importance of demographic factors in the selection of important skills (one notable exception is the consideration of experience by Lee et al., 2001). In the present investigation, despite the relatively small amounts of variance explained, there were still some interesting findings. Gender made a difference in the ranking of a total of fourteen skills, most of which were Proficiencies, including ERP, Simulation Packages, Stat ist ical Packages, and Globalization Issues. In almost all cases, females, as opposed to males, believe the skills to be more important. This finding may suggest that, to a certain degree, female and male IT professionals evaluate job skills differently, and fut ure research is needed regarding this phenomenon.

In regard to age and years in the field, pract itioners with more experience, unlike their less experienced colleagues, viewed many of the skills in the Business Expertise area as relatively less import ant for the success of entry-level personnel. For example, these professionals considered Organizational Knowledge, Business F unctions, Business Environment, and Globalization Issues as less important, as well as Office Soft ware expertise. More mature personnel have conceivably held positions in multiple organizations, thus, they may believe that company-specific knowledge can be taught on the job. Regardless, this study found that as IT professionals gain experience, they view Business Expertise skills for entry-level hires as relatively unimportant.

\section{Limitations}

This investigation has limitations. First, this study used a sample taken from six organizations that recruit entry-level IT personnel in the mid-South region of the United States. This sampling procedure may have limited generalizability to the population of all business concerns, although most of these companies operate nationwide and even globally. We feel that, at a minimum, the results of this study can be generalized to organizations operating in the same region of the United States, if not the entire country, and similar kinds of organizations operat ing beyond the United States. Second, while the sample size was satisfact ory, over half of the respondents came from one organization (the retailer), again limiting the ability to generalize. 
These noted limitations notwithstanding, it is firmly believed that the results from this study are an accurate portrayal of the needs of contemporary organizations. Many recruit entry-level IT personnel from local state universities, regional technical institutions, or trade schools. As such, this study depicts a snapshot of IT development needs that are not unusual, and not uncommon, to a vast number of organizations today. Thus, we believe that the results from this study are reflective of modern-day IT departments within the United States and, perhaps, even globally.

\section{Conclusion}

This study has empirically demonstrated that IT professionals perceive both technical and nontechnical skills as being import ant for new, entry-level personnel. The investigation confirms previous findings that non-technical skills are considered most important, especially those pertaining to Personal Attributes and Business Expertise. These soft skills are import ant as a foundation for all IT positions, and they enhance future learning and productivity as IT professionals advance in their careers. Nevertheless, technical skills are also important, though company dependent to a certain degree (different technical abilities are required for different jobs and organizations). Technical skills reduce the amount of training required of new employees and allow some entry-level personnel to be immediately productive. This study found that some other factors slightly, but significantly, influence which skills are more important to the success of entrylevel personnel, including age, gender, management level, and experience. The impact of gender was surprisingly varied: females believed (more so than their male counterparts) that entry-level personnel should possess additional skills, particularly technical ones.

An understanding of which skills are most important to new IT professionals should impact organizations at large, as well as the universities and technical schools that train fut ure IT employees. Organizations will be better equipped for new workforce training and may be spurred to interact more with universities. For their part, universities should examine curriculum, particularly with respect to enhancing soft skill areas. In addition, organizational and educational ent it ies should together explore innovative ways of pre-training entry-level IT professionals, perhaps through internships or other means of partnering.

The business climate, and in particular technology, is changing rapidly. The skills that are important today will no doubt change relatively quickly, particularly with technical expertise. It is important that the IT discipline advance with these changes, understanding which skills are most important in order to better prepare new IT employees. It is advantageous for all stakeholders, particularly organizations and educational institutions, to ensure that entry-level professionals are fully prepared to meet challenges and be ready to contribute immediately. This study has identified several issues that organizations of all types can address.

Fut ure research will include investigat ing the compliance of universities, and other inst itutions, in terms of updating curriculum to meet the skill needs of recent IT graduates. Additional research should focus on the different perspectives regarding skill needs based on gender and experience. Longitudinal studies are needed to ensure that IT professionals are adequately prepared and trained, on the front-end of their careers, with skills that will serve them well as their careers progress in an ever-changing IT world.

\section{References}

Anderson, D. R., Sweeney, D. J., \& Williams, T. A. (1996). Statistics for business and economics, Minneapolis: West Publishing.

Baroudi, J. J., \& Ginzberg, M. (1986). The impact of role variables on IS personnel work attitudes and intentions. Communications of the ACM, 29(6), 546-555. 
Cappel, J. J. (2001-2002). Entry-level IS job skills: A survey of employers. Journal of Computer Information Systems, 42(2), 76-82.

Churchill, G. A. (1979). A paradigm for developing better measures of mark eting constructs. Journal of Marketing Research, 16, 64-73.

Couger, J. D., Higgins, L. F., \& McIntyre, S. C. (1993). (Un)structured creativity in information systems research. Management Information Systems Quarterly, 17(4), 375-397.

Fang, X., Lee S., \& Koh, S. (2005). Transition of knowledge/skills requirement for entry-level IS pro fessionals: An exploratory study based on recruiters' perception. Journal of Computer Information Systems, 46(1), 58-70.

Gill, T. G., \& Hu, Q. (1998). Information systems education in the USA. Education and Information Technologies, 3, 119-136.

Gorgone, J. T., Davis, G. B., Valacich, J. S., Topi, H., Feinstein, D. L., \& Longenecker, H. E. (2002). IS 2002: Model curriculum and guidelines for undergraduate degree programs in information systems. Retrieved October 17, 2006, from http://www.acm.org/education/is2002.pdf

Gupta, Y. P., Guimaraes, T., \& Raghunathan, T. S. (1992). Attitudes and intentions of inform ation center personnel. Information and Management, 22, 151-160.

Igbaria, M., \& Baroudi, J. J.(1993). A short-form measure of career orientations: A psychometric evaluation. Journal of Management Information Systems, 10(2), 131-154.

Koong, K. S., Liu, L. C., \& Lui, X. (2002). A study of the demand for in formation technology professionals in selected internet job portals. Journal of Information Systems Education, 13(1), 21-28.

Kovacs, P. J., Davis, G. A., Caputo, D. J., \& Turchek, J. C. (2005). Identifying competencies for the IT work force: A quantitative study. Issues in Information Systems, VI(1), 339-345.

Laudon, K. C., \& Laudon, J. P. (2004). Management information systems: Managing the digital firm (8th ed.), Upper Saddle River, New Jersey: Pearson Prentice Hall.

Lee, S. M., \& Lee, C. K. (2006). IT managers' requisite skills: Matching job seekers' qualifications with employers' skill requirements. Communications of the ACM, 49(4), 111-114.

Lee, S., Yen, D., Havelka, D., \& Koh, S. (2001). Evolution of IS professionals' competency: An exploratory study. Journal of Computer Information Systems, 41(4), 21-30.

Leitheiser, R. L. (1992). MIS skills for the 1990s: A survey of MIS managers' perceptions. Journal of Management Information Systems, 9(1), 69-91.

McMurtrey, M. E., Grover, V., Teng, J. T. C., \& Lightner, N. (2002). Job satisfaction of IT professionals: The impact of orientation and task automation in a CASE environment. Journal of Management Information Systems, 19(2), 273-302.

Noll, C. L., \& Wilkins, M. (2002). Critical skills of IS professionals: A model for curriculum development. Journal of Information Technology Education, 1(3), 143-154. Retrieved from http://iite.org/documents/Vol1/v1n3p143-154.pdf

Nunnally, J. C. (1967). Psychometric theory. New York: McGraw-Hill.

Santana, M., \& Robey, D. (1995). Perceptions of control during systems development: Effects on job satisfaction of systems professionals. Computer Personnel, 16(1), 20-34.

Straub, D. W. (1989). Validating instruments in MIS research. Management Information Systems Quarterly, 10(2), 147-169.

Tang, H. L., Lee, S., \& Koh, S. (2000-2001). Educational gaps as perceived by IS educators: A survey of knowledge and skill requirements. Journal of Computer Information Systems, 41(2), 76-84.

Todd, P. A., McKeen, J. D., \& Gallupe, R. B. (1995). The evolution of IS job skills: A content analysis of IS job advertisements from 1970-1990. Management Information Systems Quarterly, 19(2), 1-27. 
Turner, R. (2004). Towards a structural model connecting hard skills, soft skills and job conditions and the IS professional: The student perspective. Issues in Informing Science and Information Technology, 1, 977-991. Retrieved from http://articles.iisit.org/123turne.pdf

U.S. Department of Labor, Bureau of Labor Statistics. (2006). 2006-2007 Occupational outlook handbook. Retrieved October 10, 2006, from http://www.bls.gov/oco/ocochart.htm

Ware, L. C. (2005, October 1). 2006 mid-year IT staffing update. CIO. Retrieved October 10, 2006, from http://www2.cio.com/research/surv eyreport.cfm? id=97

Young, D. (1996). The relative importance of technical and interpersonal skills for new information systems personnel. Journal of Computer Information Systems, 36(4), 66-71.

Young, D., \& Lee, S. (1997). Corporate hiring criteria for IS graduates. Information Systems Management, 14, 47-53.

\section{Appendix: Research Instrument Components}

Each of the items below was ranked on a seven point Likert scale

(1 = Not Important; 4 = Moderately Important; 7 = Very Important; or Don’t Know).

\begin{tabular}{|c|c|}
\hline$\underline{\text { Area }}$ & Items \\
\hline IS Core Knowledge & $\begin{array}{l}\text { Hardware (CPU, drives, memory, I/O, architecture, etc.) } \\
\text { Networks (servers, routers, hubs, fibre optics, etc.) } \\
\text { OS's(scheduling, memory allocation, threads, etc. - not just end user) } \\
\text { Mini/Mainframe OS's (z/OS, VMS, UNIX, etc.) } \\
\text { Network topologies and protocols (Ethernet, TCP/IP, etc.) } \\
\text { Mobile or wireless networks and systems } \\
\text { Databas e design/development } \\
\text { Databas e Query Language (SQL) } \\
\text { Project management (concepts, scheduling, prototyping, etc.) } \\
\text { CASE Tools (Visual Paradigm, Rational Rose, etc.) } \\
\text { Object-ori ented systems analysis and design concepts and methodologies } \\
\text { High-level languages (COBOL, VB, VB.Net, etc.) } \\
\text { Object-ori ented languages (C++, Java, JavaScript, SmallTalk, etc.) } \\
\text { Web development programming languages (JavaScript, Java, PHP, etc.) } \\
\text { Web design/publication languages (HTML, XHTML, etc.) }\end{array}$ \\
\hline Proficiencies & $\begin{array}{l}\text { Packaged offi ce-support soffware (wo rd processing and pres entation s/w) } \\
\text { Spreadsheet (Excel, Lotus, etc.) } \\
\text { Personal database (MS Acess, etc.) } \\
\text { Client-server datab ase (Oracle, DB2, etc.) } \\
\text { Web design with editors (MS FrontPage, DreamWeaver, etc.) } \\
\text { Artifi cial Intelligence (AI)/Expert Systems (ES) } \\
\text { Decision Support Systems (DSS) } \\
\text { Group Support Systems (GSS) (Lotus Notes, NetMeeting, etc.) } \\
\text { Geographi cal In form ation Systems (GIS) } \\
\text { Data warehouse/dat a mart }\end{array}$ \\
\hline
\end{tabular}




\begin{tabular}{|c|c|}
\hline & $\begin{array}{l}\text { Enterprise Resource Planning (SAP, etc.) } \\
\text { Project Management tools (MS Project, Gantt charts, etc.) } \\
\text { Simulation/optimization tools (Pro Model, Solver, etc.) } \\
\text { Statistics tools (SAS, SPSS, Minitab, etc.) }\end{array}$ \\
\hline Business Expertise & $\begin{array}{l}\text { Knowledge of your organization (products, history, customers, etc.) } \\
\text { Knowledge of speci fic business functional areas (finance, marketing, production, etc.) } \\
\text { Knowledge of business ethics and privacy issues } \\
\text { Knowledge of business information security issues (access, encryption, firewalls, etc.) } \\
\text { Knowledge of e-commerce techniques and cap abilities } \\
\text { Knowledge of general business environment (economic, legal, etc.) } \\
\text { Knowledge of globalization issues, trends, and requirements }\end{array}$ \\
\hline Personal Attributes & $\begin{array}{l}\text { Team skills (ability to work as part of a project group) } \\
\text { Communication skills (oral) } \\
\text { Communication skills (written) } \\
\text { Creative thinking skills (ability to generate new ideas) } \\
\text { Critical thinking skills (ability to analyze and evaluate) } \\
\text { Problem solving skills (ability to assess problems and choose appropriate solutions) }\end{array}$ \\
\hline
\end{tabular}

\section{Biographies}

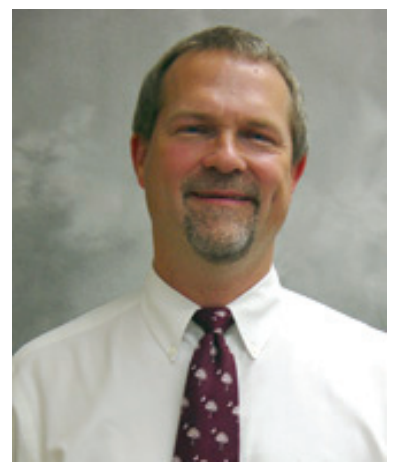

Mark E. McMurtrey is an assistant professor of MIS in the College of Business at the University of Central Arkansas. Dr. McMurtrey received his bachelors and masters degrees from the University of Arkansas at Fayetteville, and a Ph.D. in MIS from the University of South Carolina, Columbia. He has IS consulting experience with Fortune500 firms and has served on the faculties of Francis Marion University, the University of South Carolina, and the University of Idaho, among others. Besides his lengthy service and participation at various national conferences, he has published articles in the Journal of Managem ent Information System s, Computer Personnel, and Industrial Management and Data Systems, among others. His research interests include systems development processes, CASE technology, career and personnel issues of IS employees, and the matching of employer skill set requirements with recent college graduates.

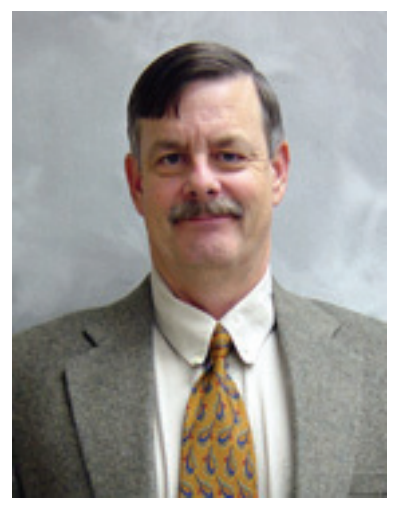

James P. Downey is an assistant professor in the MIS Department in the College of Business at the University of Central Arkansas. He received his Ph.D. in Management Information Systems from Auburn University. He spent 25 years as a Naval officer, including a tour at the U.S. Naval Academy, before leaving the Navy in November 2004. His current research interests include project management, database management, and individual differences in behavior in humancomputer interactions and end-user computing. He has presented his research at various national conferences and has been published in several journals. 


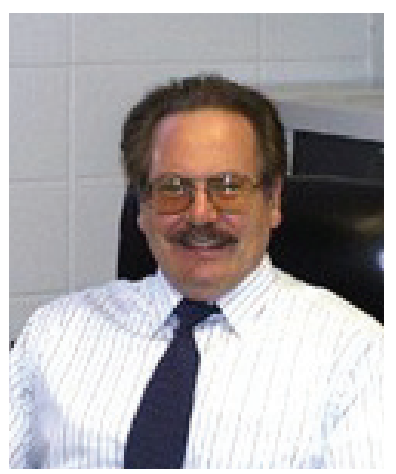

Ste ven M. Zeltmann is currently the department chair for Management Information Systems at the University of Central Arkansas. He has eamed his Ph.D. in MIS at Florida State University and also holds an MBA in Accounting from that institution. His BBA is from the University of Missouri, Columbia. Dr. Zeltmann has held CPA certificates in Florida and Tennessee prior to his academic career. Dr.

Zeltmann worked in both industry and government before becoming an academician. Dr. Zeltmann has taught at Florida State University and the University of Memphis before he joined the faculty at UCA in the fall of 2000. He has published extensively in various academic publications including two works in top MIS journals and several works in other quality academic journals. Dr. Zeltmann has also published a textbook in addition to his dissertation work, and is the current editor of the Academy of Information and Management Sciences Journal.

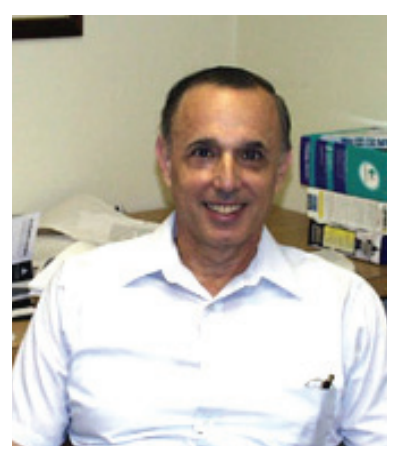

William H. Frie dman is an Associate Professor of Management Information Systems at the University of Central Arkansas. The degrees he earned arePh.D. (University of Virginia), B.A., M.A. (University of Pennsylvania), B.H.L. (Gratz College), and Post-Baccalaureate Certificate (Virginia Commonwealth University). Dr. Friedman's research extends over many areas of MIS, e.g., decision theory, artificial intelligence applications in business, programming, privacy, intellectual property, cyberslacking, out sourcing, digital divide, systems analysis, and other managerial and pedagogical factors relating to MIS and business. 